\title{
Pelatihan Kewirausahaan Keterampilan Menjahit Bagi Masyarakat Desa Damarwulan Kecamatan Kepung Kabupaten Kediri
}

\author{
Indah Yuni A. ${ }^{1}$ dan Sri Luayyi ${ }^{2}$ \\ Fakultas Ekonomi Universitas Islam Kadiri ${ }^{1,2}$ \\ indahyuni@uniska-kediri.ac.id ${ }^{1}$ dan sriluayyi@uniska-kediri.ac.id ${ }^{2}$
}

\begin{abstract}
Kediri Regency Government strives to improve the skills for the community with the goal of keeping the public is able to create their own jobs. One of the efforts in the form of Entrepreneurship skills training to saw in the village of Kepung District of Kediri Subdistrict Damarwulan. The training given by the Department of manpower and transmigration Kediri Regency and Kadiri Islamic University in the form of Devotion to the community. Forms of devotion to the community, namely the delivery of material about business opportunities in the field of tailoring, marketing and financial management. It is hoped the presence of the training community is motivated to increase his skills, entrepreneurship in the field of sewing, no difficulties in the management of working capital and easily market their products sewing results.
\end{abstract}

Keywords: training; entrepreneurship; sewing skills.

\begin{abstract}
Abstrak
Pemerintah Kabupaten Kediri berupaya terus menerus meningkatkan keterampilan bagi masyarakat dengan tujuan agar masyarakat mampu menciptakan lapangan pekerjaan sendiri. Salah satu upaya tersebut berupa Pelatihan Keterampilan Kewirausahaan Menjahit di Desa Damarwulan Kecamatan Kepung Kabupaten Kediri. Pelatihan diberikan oleh Dinas Tenaga Kerja dan Transmigrasi kabupaten Kediri dan Universitas Islam Kadiri dalam bentuk Pengabdian kepada Masyarakat. Bentuk Pengabdian kepada Masyarakat yaitu penyampaian materi tentang ide peluang usaha dalam bidang menjahit, pemasaran dan manajemen keuangan. Diharapkan dengan adanya pelatihan ini masyarakat termotivasi untuk berwirausaha, keterampilannya meningkat dalam bidang jahit, tidak kesulitan dalam pengelolaan modal kerja dan mudah memasarkan produk-produk hasil jahit.
\end{abstract}

Kata Kunci: pelatihan; kewirausahaan; keterampilan menjahit. 


\section{Pendahuluan}

Desa Damarwulan kecamatan Kepung kabupaten Kediri yang terletak di perbatasan kabupaten Kediri, kabupaten Malang dan kabupaten Jombang Jawa Timur. Pekerjaan masyarakat mayoritas adalah bekerja sebagai petani. Selebihnya adalah penambang pasir kali Konto, pegawai negeri, buruh, dan pedagang. Pemerintah Kabupaten Kediri melalui Dinas Tenaga Kerja dan Transmigrasi terus melaksanakan berbagai macam kegiatan pengembangan dan peningkatan perluasan kesempatan kerja, program penempatan dan pemberdayaan tenaga kerja yang salah satu kegiatannya berupa pelatihan kewirausahaan keterampilan menjahit yang bekerjasama dengan Fakultas Ekonomi Universitas Islam Kadiri. Materi untuk kemampuan/skill menjahit diberikan oleh instruktur yang telah ditunjuk oleh Dinas Tenaga Keja dan Transmigrasi sedangkan materi kewirausahaan disampaikan dosendosen Fakultas Ekonomi Uniska seperti mengenali potensi diri dan lingkungan, identifikasi peluang usaha, penyusunan rencana usaha, permodalan dan pembukuan.

Dinas Tenaga Kerja dan Transmigrasi membagi peserta pelatihan menjadi beberapa kelompok. Hal ini gunanya agar di dalam pelatihan ini ada suasana persaingan antar sesama peserta sehingga menimbulkan motivasi belajar. Dinas Tenaga Kerja dan Transmigrasi meminta peserta pelatihan supaya dalam enam bulan ke depan harus bisa mandiri dengan mempunyai penghasilan minimal $\mathrm{Rp}$. 1.500.000,-. Dinas Tenaga Kerja dan Transmigrasi mengingatkan bahwa keberhasilan seseorang ditentukan oleh diri sendiri maksudnya bagaimana semangat dan keseriusan menjalani pendidikan dan latihan agar cepat pandai sampai bisa membuat satu pakaian utuh dengan waktu dan keterampilan yang lebih baik.
Menurut Sugiyani, dkk (2017) bahwa salah satu cara untuk memanfaatkan potensi ibu rumah tangga dengan memproduksi pakaian atau membuat bisnis konveksi. Sehingga dapat membantu kepala rumah tangga dalam memenuhi kebutuhan rumah tangga. Dengan memberikan keterampilan kepada para ibu rumah tangga seharusnya dapat menjadi penghasilan tambahan dan berbanding lurus dengan jumlah penghasilan yang diperoleh.

Masih menurut Sugiyani, dkk (2017) bahwa kegiatan pengabdian pemberdayaan ibu rumah tangga usia produktif melalui pembinaan wirausaha mandiri mini konveksi bertujuan untuk: 1 . Memanfaatkan potensi sumber daya manusia yang dimiliki desa; 2. Memanfaatkan potensi ibu rumah tangga untuk memperoleh dana/uang tambahan guna menopang kebutuhan rumah tangga dengan mengisi waktu luang yang ada; 3 . Membentuk kelompok-kelompok usaha di masyarakat dengan fokus pada pembentukan mini konveksi; 4. Meningkatkan kehidupan perekonomian masyarakat secara langsung; dan 5. Mengurangi tingkat pengangguran.

Wirausaha jasa menjahit pakaian masih menjanjikan. Meski sekarang sudah banyak produksi pakaian jadi, tetapi jasa jahitan tetap dibutuhkan konsumen. Karena ada beberapa risiko pembelian pakaian jadi yang biasanya diterima oleh pembeli. Tidak semua pakaian jadi pas dikenakan oleh konsumen. Terutama bagi orang-orang memiliki postur berbeda dengan standar orang pada umumnya, seperti terlalu kecil atau terlalu gemuk. Disamping itu ada model dan bahan baju tertentu yang lebih enak kalau dipakai dari hasil jahitan biasa, daripada dalam bentuk pakaian jadi yang diproduksi pabrik (Berlianti. et al, 2017).

Kebutuhan akan pakaian semakin hari semakin meningkat, mulai dari anak usia sekolah sampai orang dewasa membutuhkan pakaian. Hal ini merupakan 
peluang usaha untuk meningkatkan jumlah pendapatan keluarga di desa. Beberapa permasalahan yang dihadapi masyarakat di desa Damarwulan dalam berwirausaha menjahit adalah: 1.Kurangnya pelatihan/ kursus keterampilan menjahit dari pemerintah; 2.Ketidaksediaan modal dan mesin jahit; 3.Masih terbatasnya wilayah pemasaran produk-produk dari usaha menjahit; 4.Kurangnya pengetahuan manajemen keuangan sederhana.

Pelatihan keterampilan menjahit merupakan serangkaian kegiatan yang berisi teori maupun praktik tentang menjahit. Melalui kegiatan pelatihan menjahit ini, masyarakat khususnya wanita Desa Damarwulan telah mendapat suatu pengetahuan dan keterampilan baru yang belum pernah mereka peroleh. Pelatihan keterampilan menjahit diharapkan dapat mengurangi tingkat pengangguran yang terdapat di Desa Damarwulan.

\section{Pelaksanaan Dan Metode}

Kegiatan pelatihan dirancang untuk membekali masyarakat khususnya untuk masyarakat Desa Damarwulan dengan keterampilan menjahit dan pengetahuan kewirausahaan. Pelatihan dilaksanakan atas kerja sama antara Dinas Tenaga Kerja dan Transmigrasi Kabupaten Kediri dengan Fakultas Ekonomi Universitas Islam Kadiri. Pelatihan diikuti oleh masyarakat Desa Damarwulan. Metode yang digunakan dalam program ini adalah pelatihan di dalam kelas dan simulasi proses menjahit yang dilakukan oleh intruktur dari Dinas Tenaga Kerja dan Transmigrasi.

Pelatihan adalah suatu proses yang meliputi serangkaian tindak (upaya) yang dilaksanakan dengan sengaja dalam bentuk pemberian bantuan kepada tenaga kerja yang dilakukan oleh tenaga profesional kepela-tihan dalam satuan waktu yang bertujuan untuk meningkatkan kemampuan kerja peserta dalam bidang pekerjaan tertentu guna meningkatkan efektivitas dan produktivitas dalam suatu organisasi (Hamalik, 2001).

Untuk mengetahui kebutuhan yang ada di masyarakat Desa Damarwulan, dilakukan observasi mengenai kondisi lingkungan dan kegiatan-kegiatan masyarakat,khususnya wanita baik remaja atau ibu-ibu di Desa Damarwulan. Selanjutnya, dilakukan diskusi dengan kepala desa mengenai kegiatan masyarakat sekitar untuk melengkapi data yang dibutuhkan.

Analisis data dilakukan melalui pendekatan kualitatif. Pendekatan kualitatif yang dilakukan yaitu dengan menganalisis data hasil diskusi dan observasi peserta pelatihan dalam mengikuti jalannya pelatihan.

Pelatihan dilakukan di Balai Desa Damarwulan, Kepung, Kabupaten Kediri pada tanggal 9 November 2015. Adapun rincian kegiatan adalah pembukaan oleh Kepala Desa Damarwulan, sambutan dari Dinas Tenaga Kerja dan Transmigrasi kemudian pelatihan menjahit, dan penyampaian materi tentang kewirausahaan menjahit terakhir penutupan.

Tabel 1. Materi Pelatihan

\begin{tabular}{ll}
\hline \multicolumn{1}{c}{ Materi } & \multicolumn{1}{c}{ Sub Materi } \\
\hline Menjahit Dasar & - Membuat pola \\
& - Memotong (cutting) \\
& - Menjahit (sewing) \\
& - Penyelesaian (finishing) \\
\hline Memulai Suatu & - Potensi Diri \\
Usaha & - Merencanakan Usaha \\
& - Kelayakan Suatu Usaha \\
& - Tahap Persiapan \\
& - Tahan Pelaksanaan \\
\hline Pengelolaan & - Manajemen Keuangan \\
Keuangan & Sederhana \\
& - Anggaran Kas \\
& - Piutang dan Hutang \\
\hline
\end{tabular}

(Sumber : Disnakertrans, 2015)

Pelatihan menjahit yang disampaikan oleh intruktur tentang dasardasar menjahit seperti membuat pola badan, membuat pola badan depan dan membuat pola badan belakang. Serta bahan dasar 
yang diperlukan dan berapa lama proses menjahit untuk menyelesaikan jahitan.

Materi yang disampaikan oleh dosen Fakultas Ekonomi UNISKA berupa cara memulai usaha, manajemen keuangan sederhana, dan pemasaran. Materi-materi yang sederhana ini diharapkan dapat menambah wawasan pengetahuan bagi peserta pelatihan. Kegiatan pengabdian masyarakat dilaksanakan di Balai Desa Damarwulan, Kepung, Kabupaten Kediri Jawa Timur.

\section{Hasil Dan Pembahasan}

Dalam sambutannya, Kepala Desa menyampaikan bahwa pelatihan keterampilan menjahit yang dilakukan terhadap masyarakat Desa Damarwulan belum pernah dilakukan. Padahal, ditinjau dari sumber daya manusia dari Desa Damarwulan sendiri yang notabene belum memiliki kompetensi untuk melakukan kegiatan menjahit tersebut, sehingga pelatihan ini dirasa sangat penting.

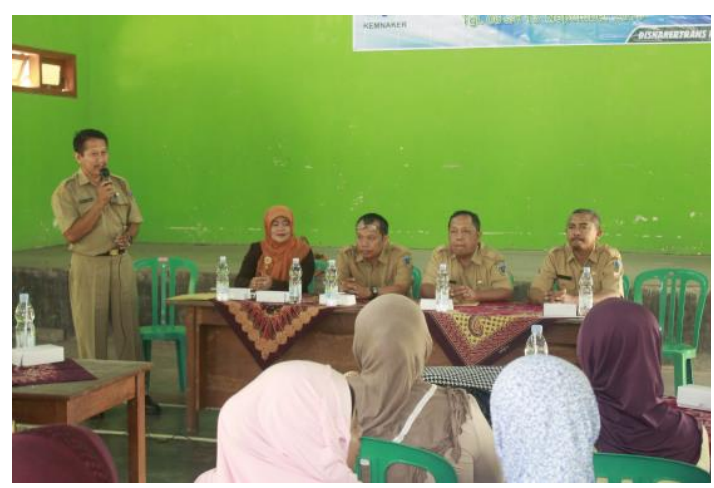

Gambar 1. Pembukaan oleh Kepala Desa

Kepala Desa dalam sambutannya menjelaskan manfaat kegiatan pengabdian masyarakat ini salah satunya dapat memberikan tambahan pemahaman kepada masyarakat desa terutama ibu-ibu. Dengan mengikuti kegiatan ini, peserta diharapkan dapat menjadi wirausahawan baru dengan membuka industri kecil menjahit yang baru dan inovatif. Harapan dari kegiatan pengabdian masyarakat yang dibuka oleh Kepala Desa, adalah agar hasilnya dapat dimanfaatkan sebaik-baiknya karena bisa memunculkan usahawan baru di dunia industri menjahit, yang nantinya bisa menjadi mata pencaharian baru.

Pelatihan menjahit diajarkan oleh instruktur yang ditunjuk oleh Dinas Tenaga Kerja dan Transmigrasi Kabupaten Kediri. Materi yang diajarkan berupa: 1.Menentukan desain dan analisnya; 2.Memilih, memeriksa dan mempertimbangkan bahan; 3.Mengana-lisis cara membuat rancangan bahan dan harga; 4.Menggolongkan peralatan untuk menjahit; 5.Membedakan alat potong yang digunakan dalam menggunting; 6.Mengidentifikasi tempat dan alat yang akan digunakan dalam proses pengerjaan busana; 7.Membedakan tandatanda pola setelah bahan digunting; 8 . Menjelaskan dan memahami cara penggunaan alat pemberi tanda serta cara pemindahan tanda-tanda pola, dan 9. Melakukan proses penyelesaian busana yang telah digunting sesuai dengan desain.

Memotong bahan dengan menggunakan mesin potong membutuhkan tempat kerja yang berbeda dengan memotong bahan menggunakan gunting biasa yang dilakukan secara manual. Memotong bahan dengan gunting biasa tempat yang dibutuhkan cukup dengan menggunakan meja potong yang sederhana. Sedangkan untuk memotong bahan dengan mesin potong tempatnya disesuaikan dengan jenis dan besarnya mesin potong yang dipakai.

Merancang bahan adalah memperkirakan banyaknya bahan yang dibutuhkan pada proses pemotongan. Rancangan bahan diperlukan sebagai pedoman ketika memotong bahan. Cara membuat rancangan bahan yaitu: 1. Buat semua bagian-bagian pola yang telah dirubah menurut desain serta bagian-bagian yang digunakan sebagai lapisan dalam ukuran tertentu seperti ukuran skala $1: 4 ; 2$. Sediakan kertas yang lebarnya sama dengan lebar kain yang akan digunakan 
dalam pembuatan pakaian tersebut dalam ukuran skala yang sama dengan skala pola yaitu $1: 4 ; 3$. Kertas pengganti kain dilipat dua menurut arah panjang kain dan bagian-bagian pola disusun di atas kertas tersebut. Terlebih dahulu susunlah bagianbagian pola yang besar baru kemudian pola-pola yang kecil agar lebih efektif dan efisien; dan 4. Hitung berapa banyak kain yang terpakai setelah pola diberi tandatanda pola dan kampuh.

Menjahit merupakan proses dalam menyatukan bagian-bagian kain yang telah digunting berdasarkan pola. Teknik jahit yang digunakan harus sesuai dengan desain dan bahan karena jika tekniknya tidak tepat maka hasil yang diperoleh pun tidak akan berkualitas.

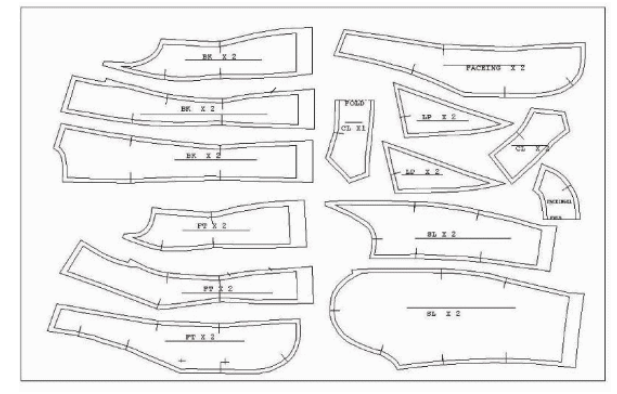

Gambar 2. Rancangan bahan

Langkah-langkah yang dilakukan dalam proses menjahit adalah sebagai berikut: 1 . Menyiapkan alat-alat jahit yang diperlukan seperti mesin jahit lengkap dengan komponen-komponen siap pakai dan alat-alat jahit tangan seperti jarum tangan, jarum pentul, pendedel, setrika dsb; 2. Pelaksanaan menjahit.

Finishing adalah kegiatan penyelesaian akhir yang meliputi pemeriksaan (inspection), pembersihan (triming), penyetrikaan (pressing) serta melipat dan mengemas. Tujuannya adalah agar pakaian yang dibuat terlihat rapi dan bersih. Kegiatan ini dilakukan setelah proses menjahit dengan mesin.

Pemeriksaan atau inpection merupakan kegiatan yang menentukan kualitas dari hasil jahitan. Pada kegiatan pemeriksaan ini dilakukan pembuangan sisa-sisa benang dan pemeriksaan bagianbagian busana apakah terdapat kesalahan dalam menjahit atau ketidakrapian dari hasil jahitan seperti ada bagian yang berkerut, ada bagian yang tidak terjahit atau ada bagian-bagian busana yang tidak rapi. Setelah dilakukan pemeriksaan ini, dilakukan pemisahan pakaian yang hasilnya baik dan yang tidak baik. Kualitas pakaian yang tidak baik biasanya dikembalikan ke bagian produksi untuk diperbaiki.

Langkah selanjutnya adalah pembersihan (trimming). Kegiatan ini dilakukan khusus di bagian quality control yang mana sisa-sisa benang dibuang dan pelengkap pakaian seperti kancing dan perlengkapan lainnya dipasangkan. Pakaian yang sudah dibersihkan dilanjutkan ke bagian penyetrikaan (pressing). Penyetrikaan yang dimak-sud merupakan penyetrikaan akhir sebelum pakaian dipasang label dan dikemas. Pressing ini bertujuan untuk menghilangkan kerutan-kerutan dan menghaluskan bekas-bekas lipatan yang tidak diinginkan, membuat lipatan-lipatan yang diinginkan, menambah kerapian dan keindahan pada pakaian serta untuk memberikan finis akhir pada pakaian setelah proses pembuatan. Penyetrikaan ini ada yang menggunakan setrika uap dan ada juga yang menggunakan mesin khusus pressing. Menyetrika merupakan pekerjaan yang harus dilakukan dengan sangat hatihati karena beresiko tinggi.Untuk itu, suhu perlu diatur sesuai dengan jenis bahan seperti linen, katun, wol, sutera, dan lainlain. Disaat melakukan pressing perlu dilakukan pengontrolan seperti tingkat kerataan bahan dan lapisan serta hasil pressing jangan sampai berkerut atau tidak rata. Pakaian yang sudah selesai di press barulah dipasang label dan dikemas.

Penyampaian materi dilaksanakan di Balai Desa Damarwulan. Target peserta adalah masyarakat khususnya ibu-ibu Desa 
Damarwulan. Penyampaian materi pertama dilakukan oleh Indah Yuni Astuti S.E., M.M. mengenai motivasi usaha, dan dilanjutkan dengan penyampaian materi kedua oleh Sri Luayyi S.E., M.Ak. yang membahas tentang pembukuan sederhana. Keduanya merupakan Dosen Fakultas Ekonomi.

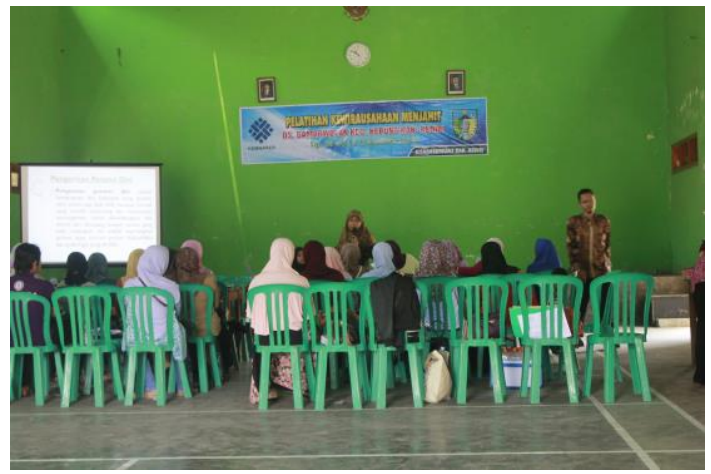

Gambar 3. Penyampaian Materi Memulai Suatu Usaha

Ibu Indah Yuni Astuti, S.E., M.M menyampaikan bahwa setiap manusia memiliki yang namanya potensi dalam dirinya. Biasanya setiap manusia memiliki potensi berbeda-beda yang diberikan oleh Tuhan Yang Maha Esa. Namun tak semua manusia menyadari akan potensi tersebut, dan terkadang bingung terhadap potensi yang mereka miliki. Padahal apabila potensi tersebut telah ditemukan maka dapat berdampak baik dalam kehidupannya. Potensi yang dimiliki manusia bisa dalam hal membuat pakaian, makanan, hiasan/kerajinan, peternakan, perdagangan, pendidikan dan usaha lain.

Dalam merencanakan usaha hal yang perlu diketahui adalah bakat yang dimiliki, produk yang kita ciptakan seperti apa, siapa pasar kita, siapa pesaing dan dari manakah modal yang kita butuhkan. Setelah itu perlu melakukan kelayakan suatu usaha berupa teknis produksi, pasar, hukum, sosial ekonomi, manajemen, keuangan, dan lingkungan.
Tahap persiapan yaitu adanya modal untuk membeli peralatan dan bahan, memiliki skill/keahlian, sabar tekun, mampu menciptakan ide kreatif dalam berproduksi, mencari referensi tempat berbelanja bahan, alat dan perlengkapan lainnya yang berkualitas dengan harga miring, dan mempromosikan usaha anda kepada orang-orang yang menjadi target pemasaran anda.

Tahap pelaksanaan yaitu jika pada awal usaha, anda merasa belum percaya diri. Maka lakukan langkah-langkah berikut: 1.Mulailah dengan menjahit potongan-potongan kain yang polanya sederhana. 2.Carilah rekan yang telah mahir dan berpengalaman dalam hal menjahit. Dengan demikian, anda dapat belajar banyak dari orang yang lebih ahli tersebut. 3.Mulailah menjahit untuk keluarga-keluarga tersekat, misalnya mencoba membuat pakaian anak, dll. 4.Dengan demikian anda dapat sering mengasah dan mengeksplor kemampuan menjahit anda.

Tips mengenali potensi yang terakhir adalah dengan yakin dan berdoa kepada Tuhan agar dapat menemukan jalan yang baik. Dengan usaha yang keras dan dibantu dengan doa, maka tidak ada yang mustahil untuk terjadi. Hal ini berlaku pada mengenali potensi sejauh mana yang dimiliki pada diri sendiri. Oleh karena itu selain usaha, diperlukan juga doa dan keyakinan terhadap potensi diri sendiri.

Ibu Sri Luayyi, SE., M.S.A menyampaikan tentang apa itu manajemen keuangan adalah cara bagaimana mengelola keuangan untuk mendapatkan keuntungan dan menggunakan sumber modal untuk pengembangan usaha. Banyak pengusaha kecil yang berpandangan jika manajemen keuangan dapat berjalan dengan sendirinya, selaras dengan jalannya usaha. Jika usaha berjalan dengan baik, maka keuangan usaha juga akan baik. Tidak bisa dipungkiri jika penjualan dan keuntungan merupakan sumber kas usaha. 
Tapi bisnis tidak semata-mata bagaimana mendapatkan uang, tapi juga bagaimana mengendalikan dan mengguna-kannya.

Manajemen keuangan sederhana yang bisa dilakukan seperti membuat anggaran kas, mengetahui perubahan arus kas, monitoring piutang klien, cek status hutang, memotong biaya operasional, memanfaatkan kredit dengan kreatif, dan menggunakan kelebihan kas untuk pengembangan usaha.

Kondisi keuangan usaha tidak terlepas dengan penjualan, kas masuk dan keluar,dan sebagainya.Dengan anggaran kas membantu memastikan bahwa usaha mampu membayar semua pengeluaran dan usaha tersebut dapat mengelola pendapatan dan pengeluaran secara efektif.

Perlu diketahui bagi usahawan bahwa beban operasional memberi dampak yang signifikan pada arus kas. Sementara kenaikan harga bahan baku membebani keuangan usaha. Arus kas dipengaruhi oleh hutang piutangusaha. Salah satu hal penting dalam manajemen arus kas adalah dengan menetapkan kebijakan kredit yang efektif. Pelaku usaha harus memiliki strategi yang dapat mendorong konsumen untuk membayar lebih cepat.

Memeriksa keuangan perusahaan dengan jadwal pembayaran hutang harus dilakukan secara rutin. Ini akan memberikan image positif dimata kreditur terhadap sebuah usaha dalam menjaga kewajiban kreditnya. Pengecekan ini untuk melihat berapa banyak perusahaan yang berhutang dan apakah usaha anda memiliki jadwal pembayaran yang sudah jatuh tempo.

Mengurangi biaya operasional dapat dilakukan dengan, misalnya menggunakan tenaga kontrak saat order meningkat, menggunakan bahan baku yang lebih murah namun dengan kualitas yang terjaga. Kemudian anda bisa mengupgrade teknologi yang anda gunakan menjadi lebih efisien. Semakin baik keadaan suatu usaha, maka akan semakin baik pula prospek usaha kedepannya. Hal tersebut akan memberi dampak pada pemberian kredit usaha menjadi lebih mudah. Penggunaan dana kredit tersebut hendaknya dilakukan dengan tepat dan efisien.

Perubahan kondisi ekonomi akan sangat mempengaruhi keuangan usaha. Hal inilah yang akan mempengaruhi pendapatan dan beban keuangan usaha. Untuk itu surplus kas bisa digunakan untuk pengembangan usaha, melunasi hutang, atau mempertahankan produktifitas usaha. Mengelola keuangan usaha merupakan salah satu hal yang sering menjadi masalah dalam sebuah usaha. Banyak usaha kecil yag terpaksa harus gulung tikar karena mengalami kesalahan dalam mengelola keuangan. Pengelolaan keuangan usaha harus dilakukan dengan cara profesional yaitu dengan memperhatikan kaidah pengelolaan keuangan bisnis.

Beberapa kesalahan yang diketemukan dalam mengelola keuangan usaha yaitu : tidak mengembangkan rencana keuangan yang jelas, tidak memahami arus kas, tidak menggunakan tenaga ahli, kurangnya pengetahuan bidang akuntansi, tidak menyadari pentingnya pengelolaan keuangan sejak awal, dan mencampur keuangan bisnis dan pribadi.

Dengan pelatihan yang sudah dilaksanakan, peserta mengerti potensi apa saja yang bisa diciptakan dari lingkungan sekitar yang nanti bisa membuka industri kreatif yang baru dan inovatif, sehingga meningkatkan kualitas keterampilan serta cara berpikir masyarakat sekitar.

Kegiatan dengan bentuk pelatihan akan memberi kesempatan kepada peserta untuk mengalami proses belajar secara lebih lengkap dan komprehensif. Hal ini sebagaimana dinyatakan oleh Afiatin et al. bahwa pelatihan merupakan salah satu cara pengembangan sumber daya manusia (Afiatin, 2013).

Pengembangan dilakukan oleh pelatih dengan memberi kesempatan belajar kepada peserta yang bertujuan 
untuk mengembangkan individu pada saat ini dan masa mendatang. Pelatih ialah seseorang yang melatih keterampilan tertentu kepada orang lain agar mampu dan mau melakukan minatnya sendiri dalam waktu yang relatif singkat. Seorang pelatih juga disebut sebagai fasilitator, yang berarti orang yang membantu orang atau pihak lain untuk belajar mening-katkan pengetahuan, sikap, dan keterampilan. Seorang fasilitator juga harus memiliki pengetahuan yang berkaitan dengan topik pelatihan, kemampuan empati, kepekaan, serta keterampilan personal dan interpersonal.

Kegiatan pelatihan kewirausahaan menjahit ini dapat mengurangi pengangguran yang terdapat di Desa Damarwulan. Kegiatan ini dirasakan menarik oleh masyarakat karena sebelumnya belum pernah mendapat kegiatan berupa pelatihan kewirausahaan menjahit. Peserta mengikuti pelatihan dengan antusias karena memiliki pandangan bahwa mereka juga dapat berwirausaha dengan memanfaatkan keterampilan ini.

\section{Simpulan}

\section{Penutup}

Berdasarkan hasil pelaksanaan kegiatan pengabdian kepada masyarakat oleh Dinas Tenaga Kerja dan Transmigrasi bekerjasama dengan Fakultas Ekonomi dari Universitas Islam Kadiri, yaitu pelatihan keterampilan menjahit bagi masyarakat desa Damarwulan kecamatan Kepung kabupaten Kediri Jawa Timur dapat diuraikan beberapa kesimpulan. 1. Kegiatan pelatihan keterampilan menjahit dirasakan banyak memberi keterampilan dan manfaat bagi ibu-ibu yang mengikuti pelatihan karena mereka belum pernah mengikuti kegiatan serupa; 2. Kegiatan dilaksanakan dengan metode penyampaian materi serta pelatihan dan diskusi yang kondusif; dan 3. Hasil dari proses pelatihan, para peserta mengerti tentang proses menjahit dan ingin berwirausaha bidang menjahit. Pelatihan keterampilan menjahit berpengaruh terhadap meningkatnya keterampilan peserta pelatihan.

\section{Saran}

Dari kegiatan pengabdian di atas beberapa saran yang dapat diberikan adalah:1. Mesin jahit yang diberikan kepada peserta pelatihan hendaklah dirawat dengan baik karena sebagai modal dasar bagi peserta; 2. Materi keterampilan menjahit hendaknya dilatih terus agar proses menjahit lebih cepat dan hasil jahitan lebih rapi; dan 3. Hendaknya peserta menumbuhkan semangat kewirausahaan dan dan dapat menciptakan lapangan usaha baru.

\section{DAFTAR PUSTAKA}

Afiatin, T., Sonjaya, J. A., \& Pertiwi, Y. G. . (2013). Mudah dan Sukses Menyelenggarakan Pelatihan: Melejitkan Potensi Diri. Yogyakarta: Kanisius.

Berlianti \& Siregar, Mastauli (2017). Kemandirian Perempuan Melalui Keterampilan Menjahit. ABDIMAS TALENTA, 2(2), 179-186.

Hamalik, Oemar. 2001. Pengembangan

Sumber Daya Manusia Manajemen Pelatihan Ketenagakerjaan Pendekatan Terpadu. Jakarta : Bumi Aksara.

Ida, Nur. (2017). Pengelolaan Pembelajaran Kursus Menjahit Pada Balai Latihan Kerja (BLK) Kecamatan Bacukiki Kota Parepare. Jurnal EMPOWERMENT, 6(2), 11-19.

Nuryanto, Wahyu. (2014). Peranan Pendidikan Keterampilan Menjahit Terhadap Peningkatan Ekonomi Warga Belajar Di Lembaga Kursus Dan Pelatihan Mandiri Kecamatan Teras Kabupaten Boyolali. Jurnal Elektronik Mahasiswa Pendidikan Luar Sekolah S1, 3(6). 
Sugiyani, Yani., Munandar, T.A., \& Harsiti. (2017). Pemberdayaan Ibu Rumah Tangga Usia Produktif Melalui Pembinaan Wirausaha Mandiri Mini Konveksi. Wikrama Parahita : Jurnal Pengabdian Masyarakat, 1(1), 32-39. http://dx.doi.org/10.30656/jpmwp.v1i 1.359 